\title{
Democratic Education of Students in Elementary School
}

\author{
Rabije Murati ${ }^{1} \quad$ Agnesa Besimi ${ }^{2}$ \\ 1.Associate Professor, University of Tetova, Faculty of Pedagogy, Ilinden Street bb, 1200 Tetovo, Republic of \\ North Macedonia \\ 2.Master's student, University of Tetova, Faculty of Pedagogy, Ilinden Street bb, 1200 Tetovo, Republic of \\ North Macedonia
}

\begin{abstract}
In this paper we will try to outline the role of civic and democratic education of students in elementary schools. The subject of this survey is the civic education, aims to prepare students as an active citizen of the future. This study is quantitative research where the students are selected in a random way.

The population of the survey is consisted of the students of primary school. The sample survey includes students of primary schools in the city of Tetova and village in the surroundings of Tetova.

We took two schools similar by number of students, but different by location. The urban school is elementary school "Istikball" in Tetovo and the rural school is elementary school "Sami Frasheri" in village of Pirok. As a method and technique of research are applied questionnaires for students in primary school, who were part of the research. The research methods are: method of data collection, theoretical analysis method, comparative method. Research Techniques and Instruments are: analysis of pedagogical documentation, survey, survey charts. Independent variables are: City, Nationality, Type of the educational institution, pupil's. Dependent variables: The opinion of pupil's from rural and urban areas about democratic, civic education; - The level of development of critical thinking and opinion of tolerance.

All the data obtained by the research are also statistically processed through: numerical data, scales, etc.

The results of this study will be comparing the differences between the groups involved in the research.

Students, citizens should choose freely, think freely, critical thinking skills, to be aware of their rights and responsibilities.

In this paper there will be information about the students democratic education, which is a major factor of democracy.
\end{abstract}

Keywords: democratic education;students; critical thinking; mass media; tolerance.

DOI: $10.7176 / \mathrm{JEP} / 10-20-04$

Publication date:July $31^{\text {st }} 2019$

\section{INTRODUCTION}

Democratization of society requires democratization of the school, and this undoubtedly emphasizes the model towards respect for the individual and personality. Only with such a pattern of education can the principles of humanism, individualism, differentiation of education and assessment of personal interests of students be applied, the democratization of education is increasingly recognized as one of the high-value values for success in reform efforts in the field of education.

Raising tolerant person can be perceived as a contribution to human culture and social good manners.

Tolerance is a virtue of moderate human society, it is the basis of a democratic and pluralistic society, it is an attitude that should be held regularly accompanied by understanding and compromise for respecting different ideas, the approach and the identity of others.

Schools in this research have been randomly selected.

\section{Methodology of survey}

1.1. Subject of the survey

Contemporary education, therefore, contemporary teaching should enable the individual to communicate effectively, not only with other people but also with technology and science in general. In 21th century education must emphasize being democratic and tolerant person and be inclusive, to prepare individuals for a better future. From this, the subject of the study of this paper is the influence of democratic education in the preparation of students for democratic life.

\subsection{Purpose and Research Tasks}

The main purpose of the research is to examine the importance of democratic education in the society. The research tasks are:

- To explore the impact of civic education on raising democratic awareness among students;

- To review how students understand the notion of tolerance;

- To explore the impact of mass media on the development of democracy 
- To explore the development of critical thinking in school.

\subsection{Hypothesis}

The general hypothesis is:

It is considered that democratic education prepares students for democratic life.

The specific hypotheses are:

1. It is assumed that the subject of civic education affects the raising of democratic awareness among students;

2. It is assumed that students understand and know the notion of tolerance;

3. It is assumed that mass media have a significant impact on the development of democracy;

4. It is assumed that the development of critical thinking at school is at a satisfactory level.

1.4. Research Methods

In this quantitative study, the research methods are:

- Method of data collection;

- Theoretical analysis method,

- Comparative method,

1.5. Research Techniques and Instruments

- Analysis of pedagogical documentation

- Survey with the students

- survey sheet for students

1.6. Sample survey

In this research will be included two elementary schools with 40 (forty) participants ninth grade pupil's, by 20 (twenty) 10 (ten) boys and 10 (ten) girls in each school, one of the municipality of Tetovo and one of the municipality of Bogovinje. And they are as follows "Istikball" in Tetovo, municipality of Tetovo and the other is "Sami Frasheri" in village of Pirok, municipality of Bogovinje. This means that the total number of involved pupil's in primary schools would be 40 pupil's and all of them are of albanian ethnicity. The time for realization the research is the school year 2017-2018.

In the research survey are applied questionnaires intended for pupil "s in primary schools. The questionnaires are composed of questions of closed type and evaluation scales in order to obtain more objective responses and to come to a more relevant knowledge about the issue that we research.

\subsection{Variables}

Independent variables:

- City

- Nationality

- Type of the educational institution

- Students gender

Dependent variables:

- The opinion of pupil`s from rural and urban areas about democratic, civic education

- The level of development of critical thinking and opinion of tolerance.

\subsection{Statistical processing of data}

The data obtained by the research are statistically processed through: numerical data, percentages, scales, etc. The purpose of statistical data processing was to establish the rate to which the democratic education of elementary school students are affected.

1.9.Analysis of the results obtained by the research

The survey included school students in urban and rural areas, 20 pupil's in each school (out of which 10 girls and 10 boys), that is, a total of 40 pupil`s; 20 girls and 20 boys. Below is present in a tabular way the gender presentation of students:

\begin{tabular}{|l|l|l|l|}
\hline & Girls & Boys & Total \\
\hline $\begin{array}{l}\text { Elementary school - Istikball } \\
\text { Tetovo }\end{array}$ & 10 & 10 & 20 \\
\hline $\begin{array}{l}\text { Elementary school - Sami Frashëri } \\
\text { Pirok }\end{array}$ & 10 & 10 & $\mathbf{2 0}$ \\
\hline Total & $\mathbf{2 0}$ & $\mathbf{2 0}$ & $\mathbf{4 0}$ \\
\hline
\end{tabular}


The first hypothesis is to investigate and clarify how much is the impact of civic education on raising Survey results are as follows:

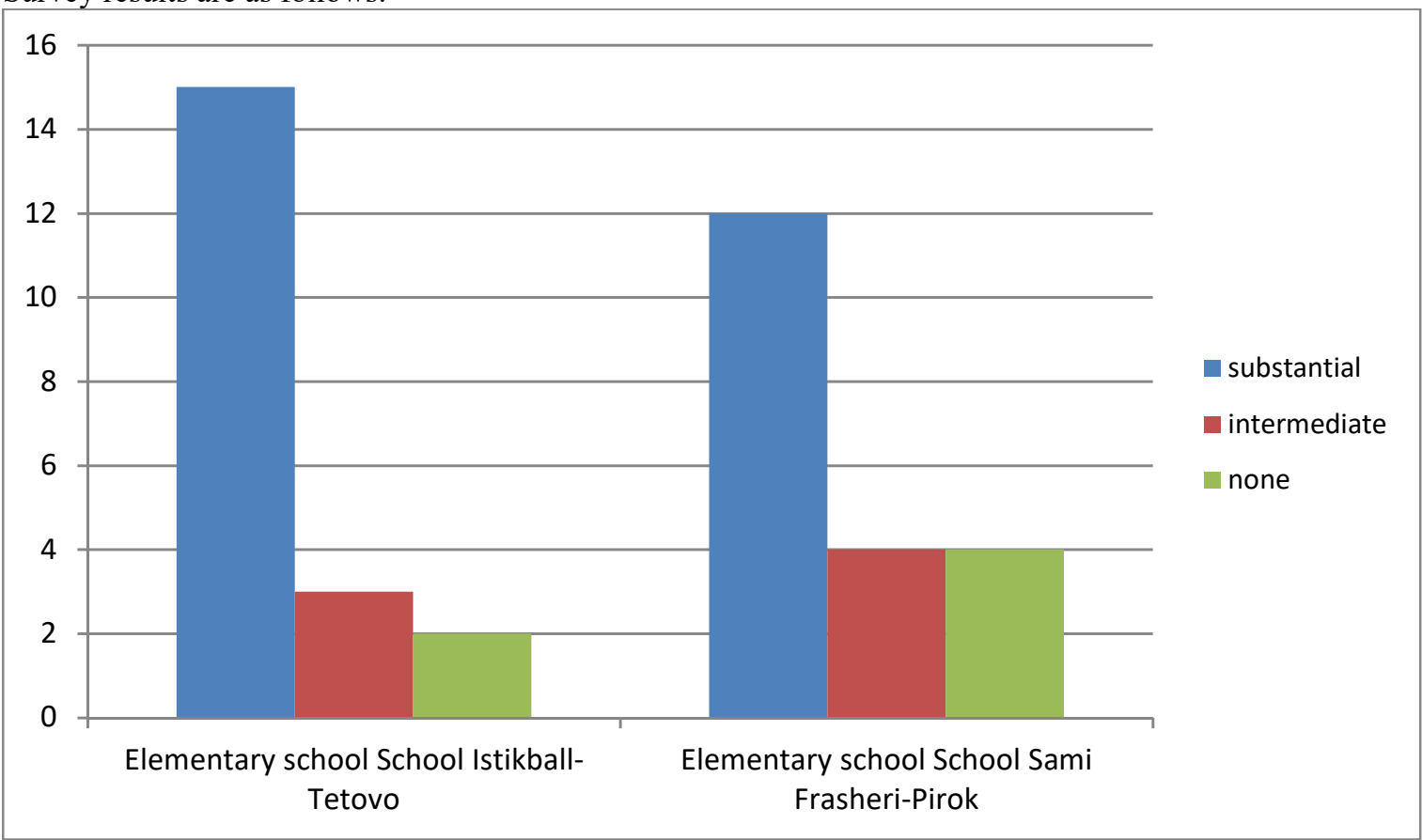

From the table we can conclude that most students think that the subject of civic education has an impact on raising the democratic awareness of the pupil's.

- The second hypothesis was that pupil`s understand and know the notion of tolerance.

The answers given in the interview list is as follows:

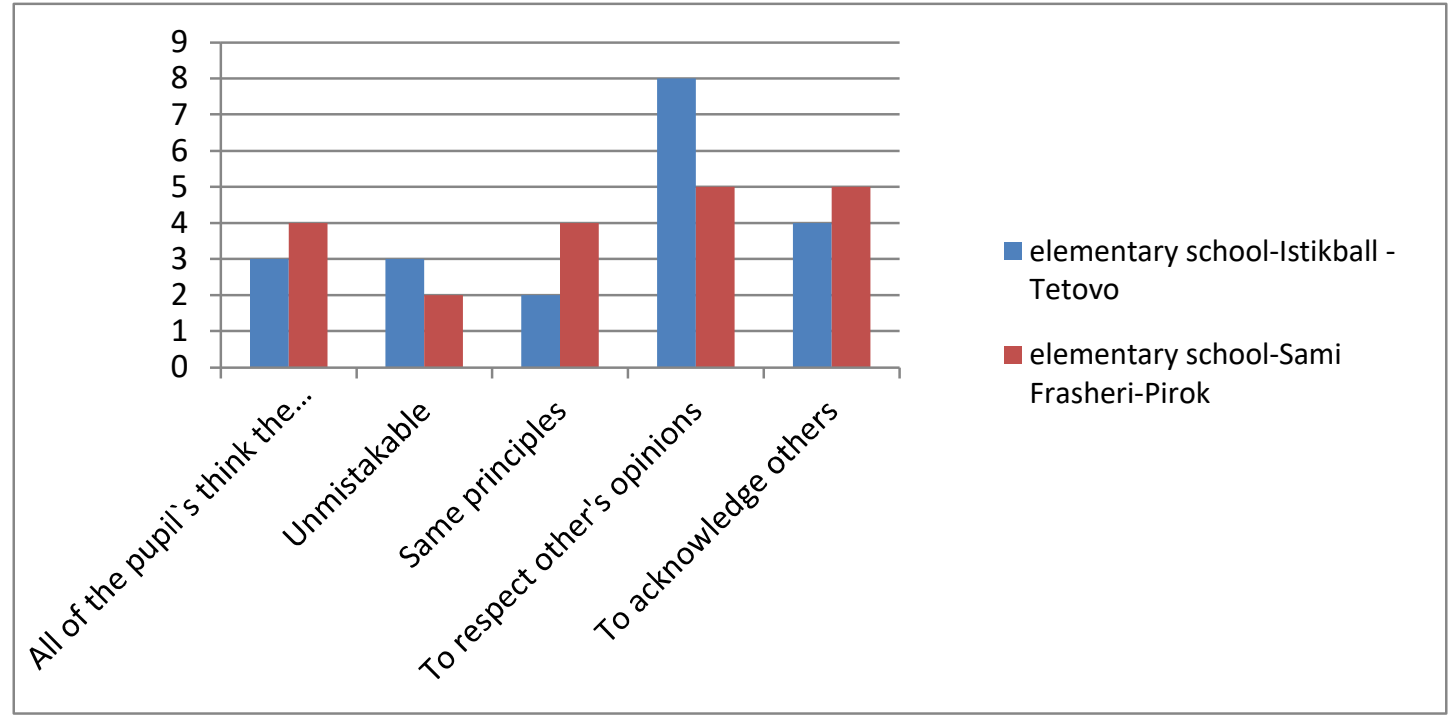

Which implies that the majority or the greater number of pupil's understand the notion of tolerance as respect for the free opinion of others.

- The third hypothesis was that mass media have a significant impact on the development of democracy. The answers given in the interview list is as follows: 


\section{The impact of the media in the developing of democracy}

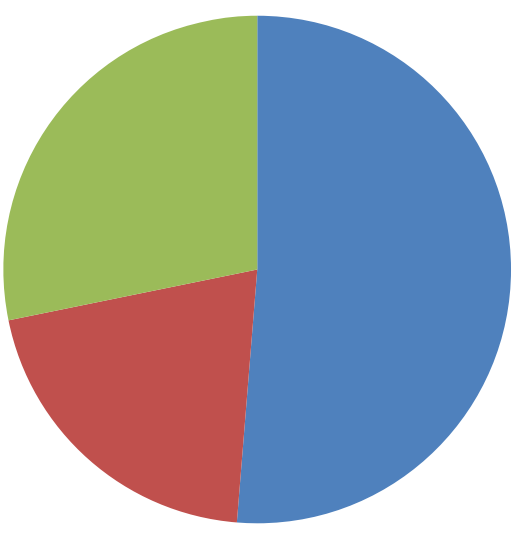

substantial

intermediate

none

From the responses received from the students of both primary schools, mass media have a major impact on the development of democracy in the country.

As to the question of which kind of media has more impact on raising and informing you as a student, answers are as follows:

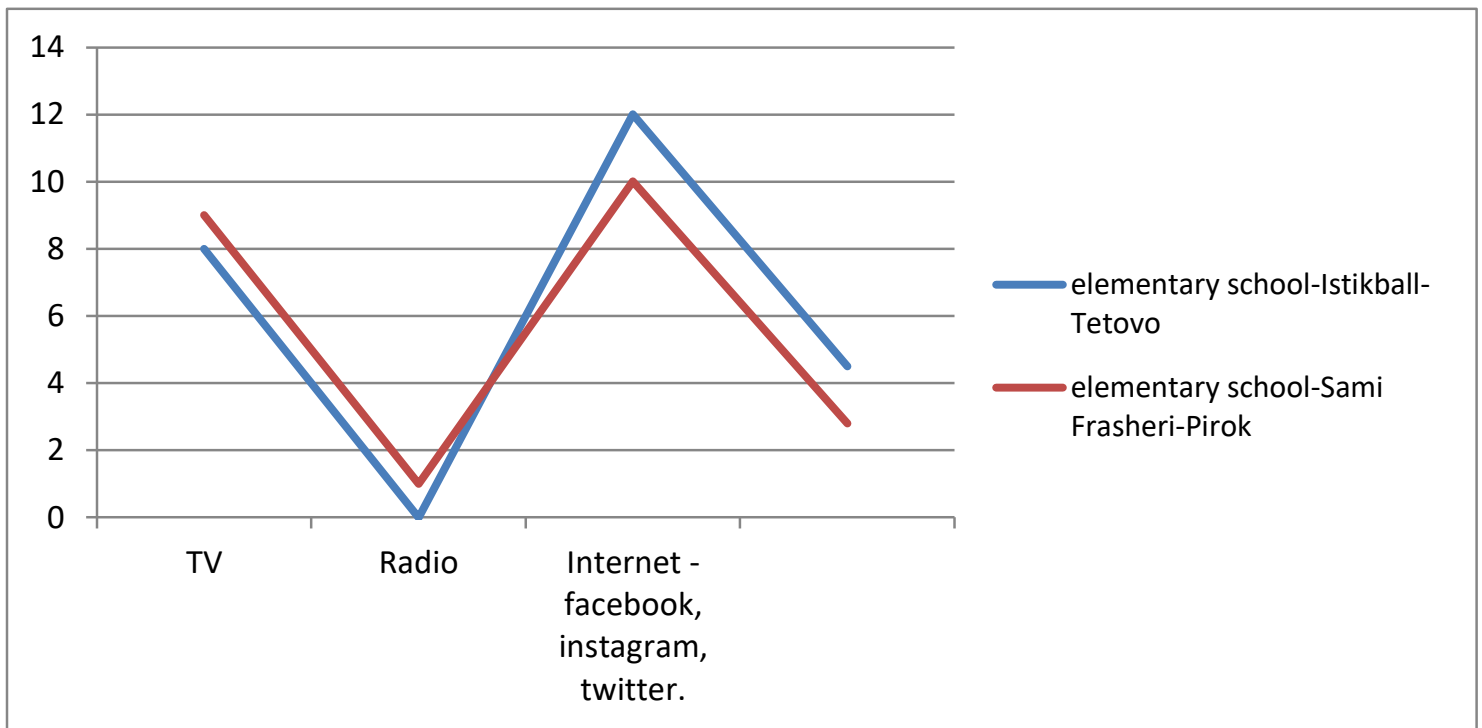

- The fourth hypothesis that the growth of critical thinking in the school is in satisfactory level the result is as follows: 


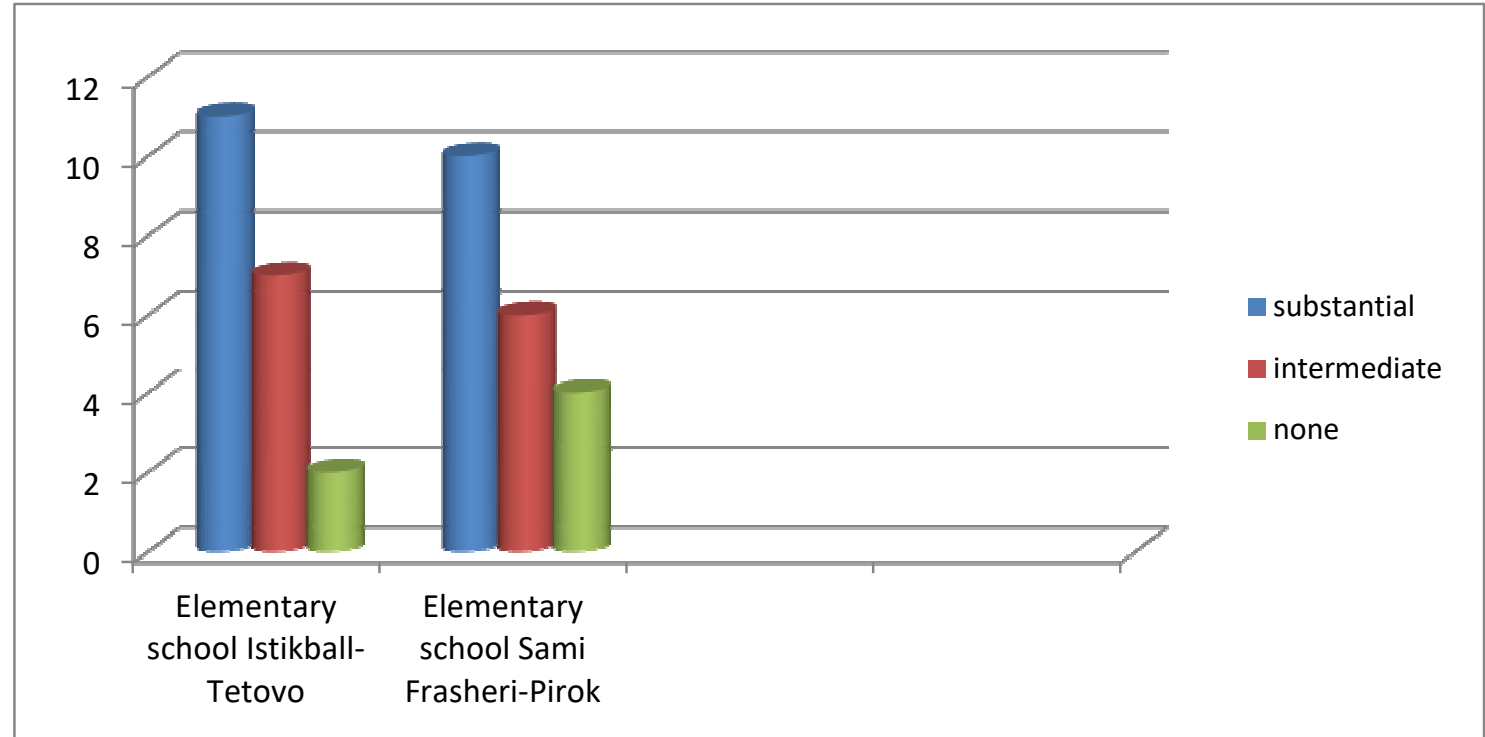

The result shows that the largest number of pupil`s, especially those in the urban school, thinks that the their school and class develops critical thinking at a satisfactory level.

\section{Conclusion and recommendation}

Conclusion

Democratic education of students is an important factor for social cohesion, mutual understanding, intercultural and religious dialogue, and solidarity.

Education in democratic society must be independent. In the sense of respecting education independence is considered as an important segment, which greatly influences the development of society as a whole through the development and formation of the individual as an important resource in the development of the state. It is considered that the most educated people are inclined or tend to more liberal and democratic values.

\section{Recommendation}

Democratic education of students in schools should be realized through their active participation in school and teaching.

Students get familiar with their rights, but also be aware of their responsibilities in a democratic society.

The student must be respected in class and at school.

Students involved in establishing school policies and changes that must take place in the school.

The teacher must respect the individuality of students.

\section{References}

1. Shosh, Edita. 1987, Demokratizacija obrazovanja, Zagreb

2. Murati,Rabije, 2016, Demokratizimi i sistemit edukativ-arsimor në Republikën e MaqedonisëLuma grafik,, Tetovë

3. Murati,Rabije, 2016, Demokratizimi i institucioneve edukative-arsimor në Republikën e Maqedonisë, Luma grafik, Tetovë

4. Murati, Rabije, 2019, Demokracia në shkollë, Luma grafik, Tetovë 